\title{
Epidemiology of Mungbean Yellow Mosaic Virus (MYMV) in Relation to Whitefly Dynamics and Weather Parameters
}

\author{
Meghashree Meti* and Mallikarjun Kenganal
}

Department of Plant Pathology, College of Agriculture, Raichur and Main Agriculture

Research Station, University of Agricultural Sciences, Raichur 584104, Karnataka, India

*Corresponding author

\begin{tabular}{|l|}
\hline Ke y w o r d s \\
MYMV, SMW, \\
Weather \\
parameters, \\
Correlation and \\
regression
\end{tabular}

\section{A B S T R A C T}

Mungbean yellow mosaic virus (MYMV) causes yellow mosaic disease in pulses. Which is most serious disease in greengram, blackgram and many pulses growing areas of North Eastern Karnataka region. The reasons for its higher incidence can be known by studying its epidemiological factors. Hence, the study was carried on epidemiology of MYMV. Epidemiological investigations involve study of weather factors, pathogen, its vectors if any, and host factors. In the present study, epidemiology of MYMV vector whitefly was investigated with weather factors like minimum temperature $\left({ }^{0} \mathrm{c}\right)$, maximum temperature $\left({ }^{0} \mathrm{c}\right)$, rainfall $(\mathrm{mm})$, minimum relative humidity $(\%)$, maximum relative humidity $(\%)$ wind speed $(\mathrm{Km} / \mathrm{h})$ and sunshine (hours) recorded daily at MARS, Raichur. In the present study, whitefly population was greatly influenced by environmental factors which prevailed during entire observation period of one year stating from $22^{\text {nd }}$ SMW of 2016 to $21^{\text {st }}$ SMW of 2017 . The least whitefly population was observed during $40^{\text {th }}$ SMW (16/trap) and $39^{\text {th }}$ SMW (20/trap) when the weekly mean maximum temperature was $28.9^{\circ} \mathrm{C}$ and 30.4 ${ }^{0} \mathrm{C}$, minimum temperature was $22.8{ }^{\circ} \mathrm{C}$ to $22.2{ }^{\circ} \mathrm{C}$ and total weekly rainfall was 60.8 $\mathrm{mm}$ for 4 days respectively. The highest number of whiteflies was noticed during $50^{\text {th }}$ SMW (1456/trap) when maximum temperature was $29.7{ }^{\circ} \mathrm{C}$, minimum temperature was $16.7{ }^{\circ} \mathrm{C}$ and rainfall of $8.2 \mathrm{~mm}$. This indicates that decrease in whitefly population was mainly due to higher rainfall and lower minimum temperature, whereas, increase in whitefly population was due to higher maximum temperature and no rainfall. Correlation and regression analysis was done to know the relationship of weather parameters with whitefly population. Results revealed that, there was a negatively significant correlation between whitefly population and minimum temperature $(\mathrm{r}=-$ $0.354)$ and positive significant correlation with maximum temperature $(r=0.250)$ was recorded. Correlation of whitefly with rainfall was negatively significant $(\mathrm{r}=-0.456)$ while other factors like relative humidity (minimum and maximum), sunshine hours and maximum wind speed showed nonsignificant correlation with whitefly population. Sunshine hours recorded shown positive relation with whitefly population $(\mathrm{r}=0.631)$. Regression analysis showed that, all these weather factors were found to contribute up to 69.6 percent towards the whitefly population and obtained multiple regression 


\section{Introduction}

The virus is most destructive in Indian subcontinent and adjacent areas of South-East Asia causing 100 per cent yield losses. It causes severe disease and economic losses in mungbean by plummeting seed yield and quality (Kang et al., 2005). The MYMV in India was first time reported by Nariani in 1960 from IARI (Indian Agricultural Research Institute), New Delhi fields with an incidence of 20-30 per cent. Several others reported the occurrence and severity of MYMV incidence from other parts of India, Sri Lanka, Pakistan, Bangladesh, New Guinea, Philippines and Thailand (Honda et al., 1983; Chenulu and Verma, 1988; Malik and Bashir, 1992; Jones, 2003; Ahmad and Harwood, 1973). MYMV also infects mungbean, soybean, mothbean, cowpea, urdbean and few other leguminous hosts (Dhingra and Chenulu, 1985 and Qazi et al., 2007). Crops infected at early stages suffer more with severe symptoms of mosaic, complete yellowing and puckering (Salam et al., 2011). The virus also causes irregular green and yellow patches in older leaves and completes yellowing of younger leaves (Nene, 1973).

Infected plant produces fewer flowers and pods, pods remain small, contain few seeds which are often malformed, shriveled, discolored, affecting qualitatively and quantitatively (Dhingra and Chenulu, 1985). Mungbean yellow mosaic virus belongs to the family Geminiviridae (Geminate means twin particles) consisting of viruses with circular $(20 \times 30 \mathrm{~nm})$, single-stranded (ss) DNA genome (Hull, 2004). These viruses are transmitted from one plant to other plant through arthropod vectors with twin particles. Geminiviridae is taxonomically divided into four genera viz., Mastrevirus, Curtovirus, Topocuvirus and Begomovirus based on host range, genome organization and insect vector. The genus Begomovirus contains viruses that are transmitted by whitefly (Bemisia tabaci Genn.) infecting dicotyledonous plants like urdbean, mungbean and soybean (Haq et al., 2011).

The genus Begomovirus has economically destructive and geographically the most wide spread viruses occurring throughout warmer parts of the world (Borah and Dasgupta, 2012). Begomovirus are consisting genomes of either one or two ssDNA genomes of $\sim 2.8$ $\mathrm{kb}$. The two components makeup the genomes of bipartite begomoviruses are known as DNA-A and DNA-B (Mansoor et al., 2003 and Jeske 2009).

The weather parameters play a vital role in survival and multiplication of vector white fly (B. tabaci) and influence the outbreak of MYMV in mungbean during crop season. Therefore, understanding of weather factors and their role in MYMV incidence is a prerequisite to provide base line information for developing disease forewarning system. However, studies in this regard and epidemiological aspects of MYMV are scanty in the North Eastern Karnataka region. Hence the present investigation focused on study of epidemiology and vector dynamics in relation to weather parameters of MYMV.

\section{Materials and Methods}

Epidemiological investigations involve study of environment, pathogen and its vectors if any and host factors. To study the epidemiology of MYMV, weather factors like minimum temperature $\left({ }^{0} \mathrm{C}\right)$, maximum temperature $\left({ }^{0} \mathrm{C}\right)$, rainfall $(\mathrm{mm})$, relative humidity $(\%)$ wind speed $(\mathrm{Km} / \mathrm{h})$ and sunshine (hours) were recorded daily at MARS, Raichur and computed to weekly intervals before using for statistical analysis. The whitefly population was correlated with these weather factors using correlation analysis software SPSS 16.0. 
For assessment of vector (white fly) population, yellow colour sticky traps (insect traps) of $33 \times 22 \mathrm{~cm}$ size were used at weekly interval at fixed location at plots no 58 MARS, UAS, Raichur campus with GPS position $16.1157468 \mathrm{~N}$ Latitude and 77.1934397 E Longitude starting from $22^{\text {nd }}$ Standard week (last week of May) 2016 to $21^{\text {st }}$ Standard week 2017. The vectors trapped were counted using magnifying lens and recorded at weekly interval.

\section{Results and Discussion}

In the present study, whitefly population was greatly influenced by environmental factors which prevailed during entire observation period of one year stating from $22^{\text {nd }}$ SMW of 2016 to $21^{\text {st }}$ SMW of 2017. Observations of weather parameters revealed higher whitefly population (170, 295 and 247/trap) during $22^{\text {nd }}, 23^{\text {rd }}$ and $24^{\text {th }}$ SMW when mungbean is usually sown in the study area. The maximum temperature in these weeks was 39.8, 33.6 and $35.3{ }^{\circ} \mathrm{C}$, minimum temperature was $26.4,24.3$ and $24.8^{\circ} \mathrm{C}$ respectively (Table 1 ). The least whitefly population was observed during $40^{\text {th }}$ SMW (16/trap) and $39^{\text {th }}$ SMW (20/trap) when the weekly mean maximum temperature was $28.9{ }^{0} \mathrm{C}$ and $30.4{ }^{0} \mathrm{C}$, minimum temperature was $22.8{ }^{0} \mathrm{C}$ to $22.2{ }^{0} \mathrm{C}$ and total weekly rainfall was $60.8 \mathrm{~mm}$ for 4 days respectively. The highest number of whiteflies were noticed during $50^{\text {th }}$ SMW (1456/trap) when maximum temperature was $29.7{ }^{0} \mathrm{C}$, minimum temperature was $16.7{ }^{\circ} \mathrm{C}$ and rainfall of 8.2 $\mathrm{mm}$. On subsequent weeks of $51^{\text {st }} \mathrm{SMW}$ and $52^{\text {nd }}$ SMW of 2016 , vector population was 1386, 1394/trap respectively. This indicates that decrease in whitefly population was mainly due to higher rainfall and lower minimum temperature, whereas, increase in whitefly population was due to higher maximum temperature and no rainfall. When the correlation of whitefly population with weather parameters was studied using statistical analysis, there was a negatively significant correlation between whitefly population and minimum temperature $(\mathrm{r}=$ 0.354 ) and positive significant correlation with maximum temperature $(\mathrm{r}=0.250)$ was recorded (Table 2). Correlation of whitefly with rainfall was negatively significant $(r=-$ 0.456) while other factors like relative humidity (minimum and maximum), sunshine hours and maximum wind speed showed nonsignificant correlation with whitefly population. Sunshine hours recorded shown positive relation with whitefly population $(\mathrm{r}=$ $0.631)$.

Regression analysis was carried out to know the relationships between whitefly population and weather parameters. The results revealed that whitefly population shares significantly positive relation with rainfall (1.587) where as other factors like minimum temperature (45.512), maximum temperature (-8.937), maximum relative humidity (-15.348), minimum relative humidity (-16.407), sunshine hours (-32.828) and wind speed (5.193) showed negatively significance. All these weather factors were found to contribute up to 69.6 per cent towards the whitefly population (Fig. 1). The multiple regression equation obtained by analysis was $\mathrm{Y}=$ $3836.283-8.937 \mathrm{X} 1-45.512 \mathrm{X} 2+1.587 \mathrm{X} 3-$ 15.348X4 - 16.407X5 - 32.828X6 - 5.193X7 (Table 3). Gupta et al., (2009) from Madhya Pradesh reported maximum whitefly population during $37^{\text {th }}$ SMW (kharif season) and their correlation analysis showed significant positive relation with minimum temperature and rainfall which is contradictory to our findings of negative relation between whitefly population and rainfall and positive relation with maximum temperature. It is mainly due to adoption of whitefly to the higher temperature in NEK region followed by suitable alternate hosts for their survival for minimum of 9 to 10 months across this tropical region. 
Table.1 Influence of weather parameters on whitefly population at weekly intervals during 2016-17

\begin{tabular}{|c|c|c|c|c|c|c|c|c|c|c|c|}
\hline |SI. No. & Weekly intervals & SMW & Number of whiteflies per trap & Max. Temp $\left({ }^{\circ} \mathrm{c}\right)$ & Min. Temp $\left({ }^{\circ} \mathrm{c}\right)$ & Rainfall (mm) & Rainy Day (No) & Max. RH (\%) & Min. RH (\%) & $\begin{array}{c}\text { Sunshine } \\
\text { hours }\end{array}$ & Wind Speed \\
\hline 1 & 29/05/2016 & 22 & 170 & 39.8 & 26.4 & 27 & 2 & 74 & 34 & 6.7 & 14.5 \\
\hline 2 & $06 / 06 / 2016$ & 23 & 295 & 33.6 & 24.3 & 45.6 & 1 & 84 & 50 & 1.7 & 9.8 \\
\hline 3 & $13 / 06 / 2016$ & 24 & 247 & 35.3 & 24.8 & 0.5 & 0 & 79 & 45 & 3.6 & 15.9 \\
\hline 4 & 20/06/2016 & 25 & 32 & 32.8 & 23.6 & 111.8 & 4 & 88 & 61 & 2.3 & 11.3 \\
\hline 5 & $27 / 06 / 2016$ & 26 & 35 & 31.8 & 23.7 & 24.2 & 1 & 86 & 58 & 1.1 & 15.1 \\
\hline 6 & $04 / 07 / 2016$ & 27 & 161 & 33.0 & 24.3 & 5.4 & 1 & 83 & 49 & 1.0 & 16.9 \\
\hline 7 & $11 / 07 / 2016$ & 28 & 152 & 32.3 & 23.8 & 8.4 & 1 & 81 & 62 & 1.6 & 19.2 \\
\hline 8 & $18 / 07 / 2016$ & 29 & 200 & 33.3 & 23.4 & 32.4 & 3 & 84 & 55 & 1.1 & 11.2 \\
\hline 9 & $25 / 07 / 2016$ & 30 & 52 & 30.3 & 23.0 & 26.8 & 4 & 92 & 68 & 0.0 & 8.6 \\
\hline 10 & $01 / 08 / 2016$ & 31 & 54 & 28.6 & 22.7 & 84.6 & 4 & 91 & 76 & 0.3 & 12.6 \\
\hline 11 & 08/08/2016 & 32 & 89 & 32.3 & 22.8 & 2.4 & 0 & 87 & 51 & 6.6 & 15.3 \\
\hline 12 & $15 / 08 / 2016$ & 33 & 133 & 33.4 & 22.9 & 2 & 0 & 84 & 47 & 6.5 & 14.1 \\
\hline 13 & $22 / 08 / 2016$ & 34 & 102 & 33.9 & 22.8 & 12 & 1 & 86 & 45 & 6.6 & 10.8 \\
\hline 14 & $29 / 08 / 2016$ & 35 & 30 & 31.2 & 23.8 & 47.2 & 2 & 88 & 51 & 2.4 & 7.8 \\
\hline 15 & 05/09/2016 & 36 & 58 & 30.9 & 22.3 & 16.5 & 2 & 87 & 57 & 5.3 & 8.0 \\
\hline 16 & $12 / 09 / 2016$ & 37 & 33 & 28.6 & 22.8 & 136.2 & 5 & 93 & 79 & 1.0 & 7.5 \\
\hline 17 & $19 / 09 / 2016$ & 38 & 31 & 28.5 & 22.2 & 79 & 4 & 92 & 63 & 1.4 & 9.3 \\
\hline 18 & $26 / 09 / 2016$ & 39 & 20 & 28.9 & 22.8 & 60.8 & 4 & 95 & 77 & 2.2 & 6.8 \\
\hline 19 & 03/10/2016 & 40 & 16 & 30.4 & 22.4 & 5.2 & 1 & 90 & 62 & 7.5 & 5.9 \\
\hline 20 & $10 / 10 / 2016$ & 41 & 28 & 31.2 & 22.2 & 34 & 1 & 90 & 58 & 6.5 & 5.0 \\
\hline 21 & $17 / 10 / 2016$ & 42 & 58 & 31.6 & 18.1 & 0 & 0 & 80 & 41 & 7.5 & 5.0 \\
\hline 22 & $24 / 10 / 2016$ & 43 & 63 & 31.4 & 16.6 & 0 & 0 & 77 & 38 & 7.6 & 4.2 \\
\hline 23 & $31 / 10 / 2016$ & 44 & 86 & 31.6 & 20.2 & 0 & 0 & 86 & 48 & 6.7 & 5.1 \\
\hline 24 & $07 / 11 / 2016$ & 45 & 132 & 31.2 & 15.6 & 0 & 0 & 81 & 34 & 7.7 & 4.5 \\
\hline 25 & $14 / 11 / 2016$ & 46 & 193 & 30.9 & 18.1 & 0 & 0 & 88 & 43 & 6.0 & 4.9 \\
\hline 26 & $21 / 11 / 2016$ & 47 & 360 & 30.4 & 14.8 & 0 & 0 & 85 & 33 & 7.3 & 4.3 \\
\hline 27 & $28 / 11 / 2016$ & 48 & 890 & 31.4 & 13.5 & 0 & 0 & 76 & 30 & 6.7 & 3.8 \\
\hline 28 & $05 / 12 / 2016$ & 49 & 910 & 31.2 & 16.7 & 0 & 0 & 82 & 38 & 7.1 & 4.5 \\
\hline 29 & $12 / 12 / 2016$ & 50 & 1456 & 29.7 & 16.7 & 8.2 & 0 & 75 & 44 & 3.8 & 6.4 \\
\hline 30 & 19/12/2016 & 51 & 1386 & 30.5 & 13.4 & 0 & 0 & 84 & 27 & 7.7 & 4.0 \\
\hline 31 & 26/12/2016 & 52 & 1394 & 30.1 & 13.8 & 0 & 0 & 84 & 28 & 7.6 & 4.4 \\
\hline 32 & $02 / 01 / 2017$ & 1 & 1096 & 30.4 & 14.6 & 0 & 0 & 74 & 26 & 7.8 & 4.3 \\
\hline 33 & 09/01/2017 & 2 & 998 & 30.4 & 14.7 & 0 & 0 & 76 & 37 & 8.2 & 6.2 \\
\hline 34 & $16 / 01 / 2017$ & 3 & 961 & 29.9 & 16.4 & 0 & 0 & 78 & 26 & 8.7 & 7.4 \\
\hline 35 & $23 / 01 / 2017$ & 4 & 996 & 31.0 & 17.9 & 0 & 0 & 78 & 32 & 8.3 & 7.4 \\
\hline 36 & $30 / 01 / 2017$ & 5 & 906 & 32.6 & 18.7 & 0 & 0 & 71 & 24 & 9.6 & 5.8 \\
\hline 37 & 06/02/2017 & 6 & 996 & 33.1 & 19.7 & 0 & 0 & 56 & 24 & 9.8 & 6.5 \\
\hline 38 & $13 / 02 / 2017$ & 7 & 1021 & 31.9 & 19.0 & 0 & 0 & 67 & 27 & 10.0 & 8.6 \\
\hline 39 & 20/02/2017 & 8 & 1211 & 36.5 & 20.0 & 0 & 0 & 57 & 14 & 10.2 & 4.8 \\
\hline 40 & 27/02/2017 & 9 & 1080 & 35.7 & 19.1 & 0 & 0 & 54 & 14 & 10.0 & 8.0 \\
\hline 41 & $06 / 03 / 2017$ & 10 & 1105 & 37.1 & 21.9 & 0 & 0 & 41 & 17 & 8.6 & 6.1 \\
\hline 42 & $13 / 03 / 2017$ & 11 & 1093 & 34.9 & 22.5 & 30 & 1 & 63 & 29 & 8.2 & 6.9 \\
\hline 43 & 20/03/2017 & 12 & 996 & 37.4 & 23.2 & 0 & 0 & 53 & 17 & 9.9 & 6.2 \\
\hline 44 & 27/03/2017 & 13 & 1008 & 39.5 & 24.9 & 0 & 0 & 44 & 16 & 9.6 & 6.4 \\
\hline 45 & 03/04/2017 & 14 & 1080 & 40.4 & 26.1 & 0 & 0 & 44 & 18 & 8.1 & 6.4 \\
\hline 46 & $10 / 04 / 2017$ & 15 & 1350 & 40.8 & 25.3 & 0 & 0 & 58 & 26 & 8.6 & 7.1 \\
\hline 47 & $17 / 04 / 2017$ & 16 & 862 & 41.4 & 27.2 & 0 & 0 & 68 & 28 & 7.9 & 8.3 \\
\hline 48 & $24 / 04 / 2017$ & 17 & 637 & 40.9 & 25.7 & 7.2 & 1 & 41 & 22 & 9.0 & 8.8 \\
\hline 49 & $01 / 05 / 2017$ & 18 & 672 & 39.6 & 26.7 & 0 & 0 & 49 & 22 & 9.8 & 7.5 \\
\hline 50 & 08/05/2017 & 19 & 583 & 39.9 & 27.0 & 0 & 0 & 59 & 25 & 7.8 & 9.2 \\
\hline 51 & $15 / 05 / 2017$ & 20 & 341 & 39.4 & 27.0 & 8.1 & 1 & 71 & 26 & 6.1 & 12.2 \\
\hline 52 & $22 / 05 / 2017$ & 21 & 244 & 42.3 & 29.5 & 0 & 0 & 59 & 20 & 6.1 & 13.4 \\
\hline
\end{tabular}


Table.2 Correlation analysis between the whitefly population and weather factors during 2016-17 at MARS, Raichur

\begin{tabular}{|c|c|c|c|c|c|c|c|c|}
\hline \multirow[t]{2}{*}{ Pearson correlation } & \multicolumn{8}{|c|}{ Correlations "r" } \\
\hline & $\begin{array}{l}\text { Whitefly } \\
\text { population }\end{array}$ & $\begin{array}{l}\text { Maximum } \\
\text { temperatu } \\
\text { re }\end{array}$ & $\begin{array}{c}\text { Minimum } \\
\text { temperature }\end{array}$ & Rainfall & $\begin{array}{l}\text { Maximum } \\
\text { Relative } \\
\text { humidity }\end{array}$ & $\begin{array}{l}\text { Minimum } \\
\text { Relative } \\
\text { humidity }\end{array}$ & $\begin{array}{l}\text { Sunshine } \\
\text { hours }\end{array}$ & Wind Speed \\
\hline Whitefly population & 1 & & & & & & & \\
\hline Maximum temperature & $.293^{*}$ & 1 & & & & & & \\
\hline Minimum temperature & $-.345^{*}$ & $.635^{* *}$ & 1 & & & & & \\
\hline Rainfall & $-.466^{* *}$ & $-.326^{*}$ & .261 & 1 & & & & \\
\hline $\begin{array}{l}\text { Maximum Relative } \\
\text { humidity }\end{array}$ & $-.635^{* *}$ & $-.781^{* *}$ & -.236 & $.447^{* *}$ & 1 & & & \\
\hline $\begin{array}{l}\text { Minimum Relative } \\
\text { humidity }\end{array}$ & $-.761^{* *}$ & $-.608^{* *}$ & .163 & $.696^{* *}$ & $.817^{* *}$ & 1 & & \\
\hline Sunshine hours & $.632^{* *}$ & $.434^{* *}$ & -.255 & $-.670^{* *}$ & $-.672^{* *}$ & $-.855^{* *}$ & 1 & \\
\hline Wind Speed & $-.444^{* *}$ & .152 & $.585^{* *}$ & .201 & .180 & $.373^{* *}$ & $-.522^{* *}$ & 1 \\
\hline
\end{tabular}

Table.3 ANOVA for regression analysis of rainfall, temperature, relative humidity, sunshine hours and wind speed in relation to Whitefly population during 2016-17

\begin{tabular}{|c|c|c|c|c|c|}
\hline \multicolumn{6}{|c|}{ ANOVA $^{b}$} \\
\hline Model & Sum of Squares & df & Mean Square & $\mathrm{F}$ & Sig. \\
\hline Regression & 8329881.101 & 7 & 1189983.014 & 14.041 & $.000^{\mathrm{a}}$ \\
\hline Residual & 3644254.075 & 43 & 84750.095 & & \\
\hline $\mathrm{R}$ & $.834^{\mathrm{a}}$ & & & & \\
\hline R square & .696 & & & & \\
\hline Multiple regression equation & \multicolumn{5}{|c|}{$Y=3836.283-8.937 X 1-45.512 X 2+1.587 X 3-15.348 X 4-16.407 X 5-32.828 X 6-5.193 X 7$} \\
\hline
\end{tabular}

X1- Maximum temperature; X2- Minimum temperature; X3- Rainfall; X4- Maximum relative humidity; X5- Minimum relative humidity; X6- Sunshine hours; X7- Wind speed 
Fig.1 Actual and predicted weekly distribution of whitefly population during 2016-17 at MARS, UAS, Raichur

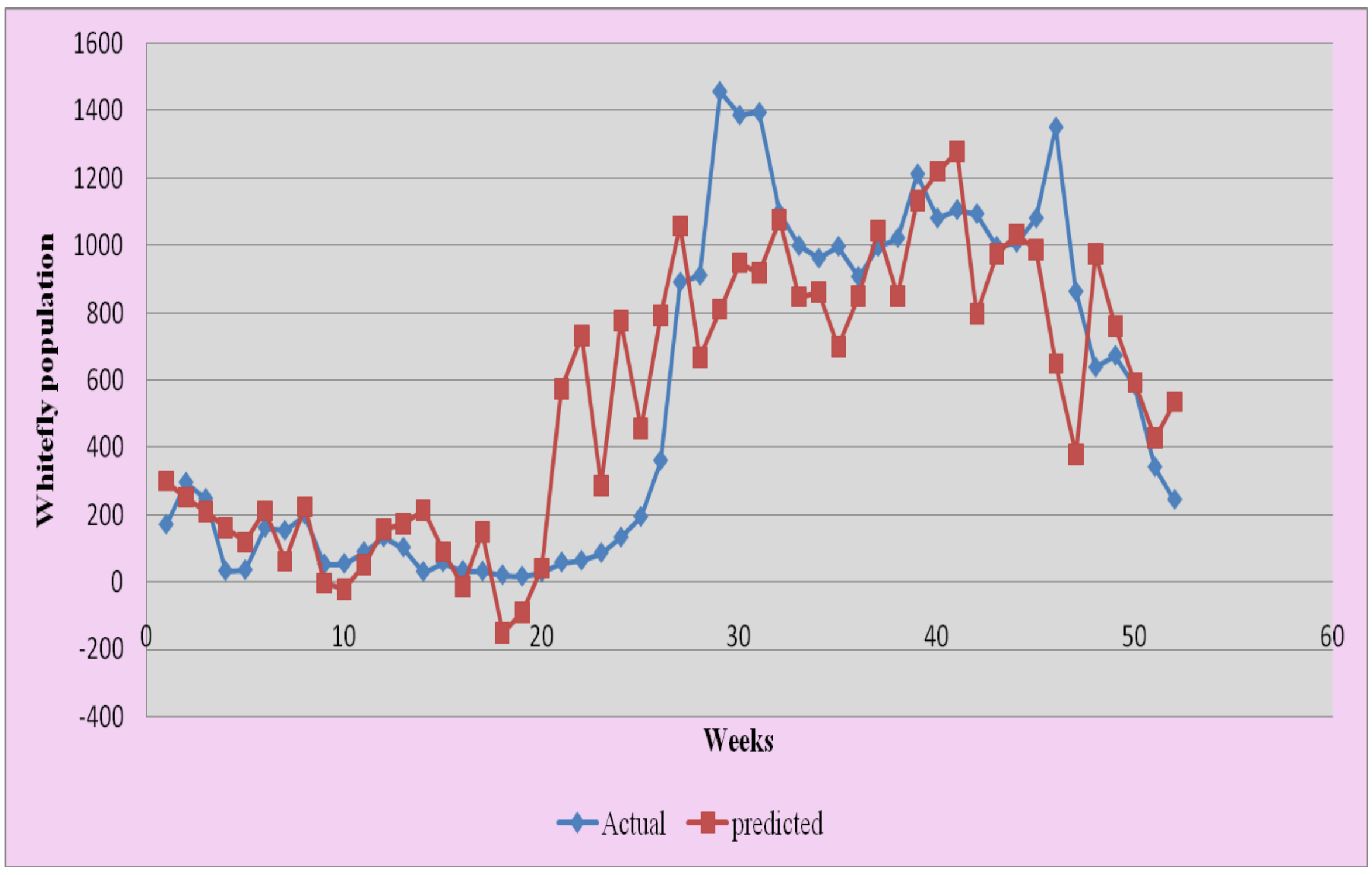


Regression analysis revealed 98 per cent contribution of weather variables on whitefly population. Sharma et al., (2013) says that positive correlation between temperature can be attributed to enhanced rate of development and reproduction of whitefly and its ovipositional activity which will be maximum at 33 to $37{ }^{0} \mathrm{C}$. The negative association between whitefly, rainfall and relative humidity is due to the disturbance of adults by rains particularly when heavy showers and strong winds occur. Cooler weather and high relative humidity are detrimental to whitefly population because whitefly population occurs when maximum temperature ranged between 34 to $36{ }^{\circ} \mathrm{c}$, minimum temperature of 24 to $26{ }^{0} \mathrm{c}$, relative humidity (morning) of 85 to 90 per cent, relative humidity (evening) of 30 to 40 per cent and sunshine duration of 8 to 8.5hours (Sharma et al., 2014). But any increase in relative humidity with cloudy weather throughout the day is going to affect the vector survival. In another study conducted by Marabi et al., (2017), they recorded the whitefly population from $29^{\text {th }}$ to $41^{\text {st }}$ SMW and noticed least whitefly population during $29^{\text {th }} \mathrm{SMW}$ and maximum population during $37^{\text {th }}$ SMW. Their correlation coefficient expressed positive significance between whitefly and maximum temperature and sunshine hours. Whereas negative correlation of whitefly population with wind speed and rainfall. Statistically significant values indicate occurrence of whitefly population as its outbreak due to prevailing ecological conditions and impact of climate change, thus our study also concludes that whitefly population is directly responsible for spread of the disease and is positively correlated with maximum temperature and negatively with rainfall.

Epidemiology study can be concluded by correlating weather parameters with whitefly population and results shows positive significant correlation of whitefly population with maximum temperature and negative correlation with minimum temperature and rainfall. It indicates that, increase in maximum temperature increases whitefly population and increase in minimum temperature and rainfall decreases in whitefly population. Thus by understanding the epidemiology one can effectively manage disease and it also helps to develop a prediction model for management of whitefly.

\section{References}

Ahmad, M. and Harwood, R. F., 1973, Studies on a whitefly-transmitted yellow mosaic of urdbean (Phaseolus mungo). Pl. Dis., 57: 800-802.

Borah, B. and Dasgupta, I., 2012, Begomovirus research in India: A critical appraisal and the way ahead. $J$. Biosci., 37 (4): 791-806.

Chenulu, V. V. and Verma, A., 1988, Virus and virus-like diseases of pulse crops commonly grown in India. In: Baldev, B., Ramanujam, S., Jain, H. K. (Eds.), Pulse Crops. Oxford and IBH, New Delhi, 338-370.

Dhingra, K. L. and Chenulu, V. V., 1985, Effect of yellow mosaic on yield and nodulation of soybean. Indian Phytopathol., 38: 248-251.

Gupta, M. P., Nayak, M. K. and Srivastava., 2009, Studies on seasonal activity of whitefly population and its association with weather parameters. $J$. Agrometeorol., 12(2): 186-189.

Haq, Q. M. I., Arif, A. and Malathi V. G., 2011, Infectivity analysis of a blackgram isolate of mungbean yellow mosaic virus and genetic assortment with MYMIV in selective hosts. Virus Res., 42 (3):429-439.

Honda, Y., Iwaki, M. and Saito, Y., 1983, Mechanical transmission, purification and some properties of whitefly-borne 
mungbean yellow mosaic virus in Thiland. Pl. Dis., 67: 801-804.

Hull, R., 2004, Mathew's Plant Virology. Fourth Edition. Elsevier Publishers, India, pp.180-182.

Jeske, H., 2009, Geminiviruses. Curr Top Microbiol Immunol. 331: 185-226.

Jones, D. R., 2003, Plant viruses transmitted by whiteflies. European J. Pl. Pathol., 4 (1): 195-219.

Kang, B. C, Yeam, I. and Jahn M. M., 2005, Genetics of plant virus resistance. Annu Rev Phytopathol. 43: 581-621.

Malik, B. A. and Bashir, M., 1992, Major diseases of food legume crops of Islamic countries. In: Jamil, F. F., Naqvi, S.H.M. (Eds.), Proceedings of COMSTECH-NAIB International Workshop of Agroclimatology Pests and Disease and Their Control. Pp. 2538.

Mansoor, S., Briddon R. W., Zafar, Y., Stanley, J., 2003, Geminivirus disease complexes: an emerging threat. Trends Plant Sci. 8:128-134.

Marabi, R. S., Das, S. B., Bhowmick, A.K., Pachori, R., Vibha, H. and Sharma, H. L., 2017, Seasonal population dynamics of whitefly in soybean. J. Entomol. Zool. studies., 5(2): 169-173.

Nariani, T. K., 1960, Yellow mosaic of Mung (Phasoelus aureus L.). Indian Phytopathol., 13: 24-29.

Nene, Y. L., 1973, Viral diseases of some warm weather pulse crops in India; Plant Dis. Rep. 57 463-467.

Qazi, J., Ilyas, M., Manseor, S. and Briddan, R. W., 2007, Legume Yellow Mosaic Virus: genetically isolated begomovirus mole. Plant Patholo., 8 (4): 343-348.

Salam, S. A., Patil, M. S. and Byadgi, A. S., 2011, Satus of munbbean yellow mosaic virus disease incidence on greengram. Karnataka J. Agric. Sci., 24 (2): 247248.

Sharma, S., Maqbool, A., Ahmad, H., Kuldeep, S., Manoj, K., Vishav, V. and Singh, J., 2013, Effect of meteorological factors on the population dynamics of insect pests of tomato. Veg. Sci., 40 (1): 90-92.

Sharma, S., Yogesh, K. and Shyam. S., 2014, Influence of abiotic weather parameters on population dynamics of whitefly, Bemisia tabaci (Genn) on cotton. $J$. Cotton Res. dvpt., 28(2): 286-288.

\section{How to cite this article:}

Meghashree Meti and Mallikarjun Kenganal. 2018. Epidemiology of Mungbean Yellow Mosaic Virus (MYMV) in Relation to Whitefly Dynamics and Weather Parameters. Int.J.Curr.Microbiol.App.Sci. 7(09): 2368-2375. doi: https://doi.org/10.20546/ijcmas.2018.709.294 